\title{
Waning Morality and Fidelity in African-Nigerian Society and the Hidden Betrayal in Globalization and Modernity: The Role of the Media
}

\author{
Edih, O. University ${ }^{1 \star}$, Umuze, N. Anthonia $^{2}$ and University, E. Ebitare ${ }^{3}$ \\ ${ }^{1}$ Marine Economics, Nigeria Maritime University Okerenkoko Delta State, Nigeria. \\ 2Mass Communication, Delta State Polytechnic, Ugwashi-uku, Delta State, Nigeria. \\ ${ }^{3}$ English Education, National Open University of Nigeria, Abuja. \\ ${ }^{*}$ Corresponding Author E-mail: oweilade123uni@gmail.com
}

Received 3 January 2022; Accepted 23 February 2022; Published 25 February 2022

\begin{abstract}
The spate of societal decadence, declining moral values, and infidelity African society is becoming worrisome because it's turning into an accepted norm in this new world championed by the actions of colonization, modernity and globalization. In fact, it's regarded as the modern culture and means of livelihood. This study x-rayed the waning morality and fidelity in AfricanNigerian society: the hidden betrayal in modernity and globalization. The issues on moral decadence, juvenile delinquency, infidelity, immoral and unethical behaviors, get-rich-quick syndrome, uncontrolled promiscuity and lewdness, broken marriages and homes, corruption in public office and related vices prevalent in modern era were critiqued and juxtaposed with socio-cultural behaviors in pre-colonial days in Africa. This was done through oral interview, review of literature, critical observation of societal behaviors. This study discovered that there is a grave rot in the society and that it would be a herculean task to sustain the norms and values of the African traditional society in this digital economy. It was found that the new world has displaced and altered the former communal and kindred culture and that in no distant time there may be no African tradition and custom. It was contended that the ills or excesses associated with globalization or modernity may only be managed but would be an impossible task to eradicate because the world is a global empire regulated by information system and knowledge available to all. It is therefore recommended that the government, religious bodies, non- governmental agencies, Kings and Chiefs, heads of families and wellmeaning individuals should awake to their responsibilities of advocating and inculcating moral values into the youths, children and wards. The mass media platforms should be vigorously harness to advance the Africa cultures.
\end{abstract}

Keywords: Africa, betrayal, fidelity, globalization, morality, modernity, Nigeria

\section{INTRODUCTION}

African traditional society is known and revered for its strict adherence to moral values and fidelity before the advent of colonization, globalization or this modern world. Prior to colonialism, traditional society had organized kindred structure where everyone was his or her brother's keeper. The culture of being one's brother keeper was referred to by God in the Bible when He asked Cain where is your brother Abel, but Cain replied "am I my brother's keeper". So, it could be inferred that being a brother's keeper' is an attribute of God and an age long tradition and virtue. Africans were superb in inculcating moral values into their children and wards but now, it scaling downward. Communal life and social behaviours and relationships were regulated by societal norms, values and customs of the land. Moral values were fundamental to communal and kindred relationships and interactions. Though, these norms and values were the laws, they were largely unwritten hence flexible to accommodate innovations and new trends (Obilade, 2011). The laws that regulate the activities in the community were written in the hearts of the people. Traditional customs and practices were transferred from 
one generation to another through forklores, celebration of festivals and constant practice by the people. The structure of government in Africa starts from the family to the village quarter- level and to the village head. In some traditional arrangements, the king controls the kingdom through the assistance of chiefs and village heads. There was law and order in African traditional society. Security was enhanced through the actions of able bodied men and traditional hunters/warriors who are highly respected in the community. Criminal elements were not as pervasive as they obtain today. When an individual breaches the code of conduct, the appropriate sanction in line with the traditions and customs was meted on the perpetrator without fail (Edih, 2020).

Every family in African-Nigerian traditional society has a name to maintain and such family will go to any length in order to preserve the legacy of its forebears. Based on the sanctity associated with family name, miscreants are not condoned within the dim past. Members of the community knew their sacred functions that must be carried out as at when due. The communal interactions and relationships between members and communities in African traditional society were endearing and enduring. Men and women played their respective roles of nurturing and mentorship while the youths and children respected their parents and obeyed commands and instructions.

The African-Nigerian traditional society was peaceful and loving because hard work was cherished and diligent men and women were rewarded with titles either by the village head or the king. In those memorable days, it was a taboo for a woman to dress flippantly with transparent clothes. The dressing culture was highly esteemed by all. The culture designs the patterns of clothes for married women, young ladies, men and young men as well as the title men and women in the community. The dressing styles distinguish men, women and title personalities from other categories of persons in the community. The culture and customs also address the different days assigned as market days, the forbidden animals and fishes and some forbidden behaviours that attract punitive measures (Edih, Ogemohia and Faghawari, 2022).

Nowadays, this pleasant story has changed. A new world has taken over the old African traditional society. The new world came with its culture, laws and orders. This contrasting configuration is alien to African-Nigerian traditional cultures. In this opposing controversies, some schools of thought appreciate the new world referred to as modernity or civilization while the other schools of thought canvass for the preservation of the old African traditional custom and way of life (4). This discourse on waning morality and fidelity seeks to examine the moral rot, defilement of the traditional heritage, diminishing ancestral traits and attendant consequences on the African-Nigerian society. The study also seeks to find answers to the following questions;

1. Can the old African traditional customs and way of life be sustained?
2. Will the new world accommodate the old traditions of Africa?

3. Are the people in love with the way of life of their forebears or the modern lifestyle?

4. Can anything be done to eradicate the presumed excesses or ills in the social behaviours in modern society?

Based on the above background, this study would be done under five sections; introduction, review of literature (social behaviours in modern society, studies on social behaviours and modernity), Method of interview, findings/interview report, the role of the media and conclusion. It is hoped that the recommendations of the study would help governments and relevant institutions in Africa to make laws and formulate policies that would address this global menace.

\section{Review of related studies}

\section{Social behaviors in modern and global society}

The whole wide world is regarded as global village due to the presence of information technologies (Hill, 2009). Majority of the world's population have access to information through social media platforms. Castells describes the new world as knowledge processing economy (as cited in Robinson, 2007). It is easy to get to any part of the globe through transportation systems (air, land or sea) at most in few hours or days. The sociocultural endowments of the traditional world have been altered by the actions of modernity or globalization facilitated by colonization and/ or vice versa. The colonization of Africa by the British and France Colonial masters was the commencement of the social reengineering in Africa. The colonial masters came with their government structure, occupied Africa land with new doctrines, new way of life, new language, new educational standard, new commerce and economics (Walter, 1987).

Based on this new composition, Africans were reengineered and re- oriented to believe in the superiority of the Colonial master's culture. Africans were taught a new language and given foreign names known as baptismal names because of accepting the new faith in Jesus Christ. According to Chinua Achebe, many Africans abandoned the religion of their fore fathers to the warm embrace of Jehovah (Chinua, 1958). Some Africans are founders of modern Pentecostal churches (Deeper Life Bible Church, Redeemed Christian Church of God, Faith Tabernacle, etc) apart from the ones sponsored by the missionaries (such like Catholic Church, Anglican Church, Methodist Church, Seventh Day Adventist Church) who came along with the colonial masters. It is apposite to mention that, Africans are also proprietors and proprietress of many model schools ranging from primary to tertiary institutions. In the world of scholarship, there are a lot of Africans, Nigerians who 
have excelled in the academia and knowledge through training and social re-engineering by the colonial masters and civilization or modernity. Wole Soyinka is a proud African-Nigerian who won the Nobel laureate prize. Nowadays, a large number of Africans travel across the globe as merchants seeking for business partners and contracts. Kwame explained that exposure to world's commerce and economics brought a new horizon that has transformed the lifestyles of the African elites (as cited in Edih et al., 2022).

Modernity and globalization brought a new form of democratic government to Africa. Prior to colonization, Africans were governed by their kings, Obas and village heads (Edih, 2020). There was nothing known as a State or Country. The continent of Africa was balkanized by the Colonial Masters to ease their exploration and exploitation agenda at the Berlin Conference in 1884.Before the conquest and eventual balkanization of Africa, every enclave of people with common ancestral lineage and common language was ruled by the accepted form of leadership, monarchical, egalitarian or otherwise. Leadership was orchestrated by the gods of the land whom the people pay allegiance and worship. Africa religion is rooted in the traditional belief system. These gods represent the will of the society (Alphonse, 2010). The imposed democratic system of casting the ballot is strange to the people of Africa. That is why, independent nations in Africa are constantly confronted with multifarious issues hampering good governance and causes of marginalization, oppression, military coups, agitations for secession (Biafra agitators, Niger-Delta militants, Oduduwa agitators, Middle-belt movement, etc). The force marriage among diverse ethnic groups to form a cosmopolitan State is the bane of unity in Africa States. The study of Levis, Gary and Charles (Edih et al., 2022) revealed that Nigeria is made of over 300 ethnic groups (Izon, Urhobo, Isoko, Edo, Itsekiri, Ibo, Yoruba, Hausa, Fulani, Tiv, Igala, etc) with different languages and since Independence in 1960, the country has been grappling with problems of governance. Chinua Achebe once said that 'the problem of Nigeria is leadership' because electing a leader through the ballot box is alien to African people. Obafemi Awolowo did not believed in the Nigerian project, according to him, Nigeria is 'a mere geographical expression' not an independent State. So, can it be concluded that, colonization, modernity or globalization brought confusion to Africa?

The global village economy came with the smart ways of doing things. The world has metamorphosed into a digitally controlled system and humans have adjusted to the current reality of life. In the opinion of Kwame (as cited in Edih et al., 2022) this smart world orientation has influenced the reasoning and dressing patterns and in fact the general lifestyle of the African-Nigerian people (woman inclusive). The modern African woman is equipped to do the jobs that were hitherto categorized as men's jobs. Africa can boast of thousands of women who are medical doctors, certified engineers and architects, pilots, armies, footballers, athletes and so on. Based on these proffered reasons, Africa women prefer dressing like men with the excuse that it makes them look smart and the work environment does not allow dressing the African traditional style. More so, their fellow women and ladies in the developed world look smart, agile and fit with the modern dressing attire/clothes. In pre-colonial era, the traditional African woman is not permitted to put on wears that portray them as men but, those days are (gradually) fading fast. It's rather an accepted norm in Africa and Nigeria or African women are stubbornly putting on shorts, trousers, transparent clothes which expose their physical contours, cleavages and shapes.

On the other hand, some African men are scientifically and medically transforming themselves to women without justification whatsoever. Some blame their creator (for those who believed in the existence of a Creator- God) for being men because they preferred to be women. Modernity or civilization has caused some persons to believe in gay or lesbian marriage. Some also believed in bestiality (Reshma, 2015). Every evolving social behaviour is a new coloration and normal trend in this digitalized global village. The get-rich-quick syndrome perpetrated through yahoo business and other fraudulent transactions are applauded by majority of the people and the society is beginning to allow it as a way of life. Therefore, the attributes of diligence, hard work, focus, vision etc are no longer regarded. Some scholars have alluded the cause of these negative changes in social behaviour to the aftermaths of globalization (Ogechukwu et al., 2016; Eze, 2014,). It could also be traceable to unemployment and bad government.

\section{Studies on globalization and moral values}

According to Lemke (1993), globalization, modernity affects cultural practices and that the changes occasioned by actions of globalization and the new world on traditions and customs cannot be regulated by man. It has been observed that Africans, Nigerians have abandoned their mode of worship, mode of marriage, mode of dressing, mother tongue, and behaviours. Modernity and education have caused some Africans to disregard the traditional norm of total loyalty to their spouses (Edih, et al., 2022). Though, Eze (2014) suggests that increase in human knowledge, standard education, advancement in science and technologies are products of globalization and modernity. In line with Castells research, there is a connection between the forces of informational technologies and culture and the projections in human society are due to global drivers (as cited in Robinson, 2007).

Africans, Nigerians are made to accept values that are conflicting with their traditions, customs and culture. The traditions of Africa do not accept and do not permit gay, lesbians or same sex marriage. It a grievous taboo in 
Africa land (Eze, 2014). In Reshma (2015), it was observed that Indian's culture hates hydras and transgender culture. The transportation of lesbian, gay, bisexual and transgender (LGBT) to developing nations is destroying the indigenous sexual culture of fidelity in marriage and family lives. Reshma also argued that colonization and globalization facilitated the importation of new sexual culture into India and other developing countries. However, there is discrimination against hydras in India and indeed Africa.

Morality and fidelity are strong moral values in African tradition but modernity through telecommunication and internet services at the disposal of majority of modern generation in Africa and Nigeria, have influenced many to acculturate, accept and embrace the new way of life leading to forwardness, rascal, party freak lifestyles (Edih et al., 2022). Kwame had observed earlier that globalization brought about the growth and penetration of global culture on traditional lifestyles, tastes and desires. This has caused great erosion of African, Nigerian cultures (Nicolaides, 2012). lyang (Edih et al., 2022) declares that the effect of globalization on culture is the most controversial debate because it is rampaging. Globalization, otherwise termed as modernity exerts great pressure on the people's culture (Ogechukwu et al., 2016) and Oni (Edih et al., 2022) also contends that it is destructive to the culture and development of Africa.

The new world has resulted to dislocation in the moral values in Africa. Africans prefer the whiteman's religion and culture. Religion, being product of colonization and globalization was used as a mechanism for social reengineering and re-orientation (Herrington, 2013). Some scholars see religion as the opium of the masses according to Karl Marx while others thank God for the new grace it brought to liberate Africans from idolatry and eternal bondage under Satan. They prefer purchasing goods made in Europe to home made products. Africa is a washed with modern fashion whose root is the developed economies of the world. Fuch (2010) describes this orientation as new imperialism, critical globalization studies which see the world as an empire. It further emphasizes the dominance of the developed economies over third world countries through the exercise of capitalist ideology.

According to empire theory, the concentration of capital in the Western World led to capitalism and the capital export outside Europe is the brain behind economic and political divisions of the world. The confusion in economic, political policies in Africa could be said as the attribute of colonization, modernity and globalization. Appradurai's thesis sees the major ache of today's global interactions as the conflict between cultural homogenization and cultural heterogenization (as cited in Robinson, 2007). On the basis of this stark reality, has anything good come out from modernity and globalization? Has Africans, Nigerians benefited from the actions of modernity and globalization?

\section{METHODS OF INTERVIEW}

The study adopted a qualitative survey research method. A total number of 150 participants were selected using census sampling method. The selected participants were grouped into old generation and modern African youth. These groups were categorized based on age demography (Table 1).

Table 1: Demography of participants.

\begin{tabular}{llcc}
\hline Groups & & Frequency & Percent \\
\hline Old generation: & Men. & 40 & 26.67 \\
& Women. & 35 & 23.33 \\
Modern youth : & Boys & 50 & 33.33 \\
& Girls & 25 & 16.67 \\
& & 150 & 100.00 \\
\hline
\end{tabular}

Every selected participant that is above 50 years was classified as old generation and below 50 years as modern African Youth. The interview was carried out separately by the three authors at different times and places in Nigeria (Asaba in Delta State, Yenagoa in Bayelsa State and Port Harcourt in Rivers State). Each of the three interviewers was assigned 50 interviewees. Responses from the participants were summarized in line with the interview questions as shown below;

\section{Interview Report}

\section{Modern culture and traditional African culture, which do you prefer?}

\section{Synthesized response}

The old generation of Africans prefer the good old days. They believe in the traditions and customs of Africa. If possible, it should be resuscitated and sustained. However, modern African youths are happy with modernity and globalization. It makes life easy and void of dogma and beliefs. This finding is line the study of Appradurai's thesis which conclude that there are tensions between the new world and the culture of people due to global interactions (as cited in Robinson, 2007).

Do you think, we can maintain the traditions and customs of Africans in this modern world?

\section{Synthesized response}

The old generation responses were in the affirmative while the young men and women responses were negative in total embrace of the new breeze of life.

\section{Is African traditions fading away?}

\section{Synthesized response}


Both groups agreed that African culture is gradually fading away.

\section{Is there need to revive the African culture?}

\section{Synthesized response}

The old generation insist on holding to African-Nigerian way of life because it is better and peaceful. But the modem youths disagreed.

\section{Should the traditions of the African society be forgotten so that we embrace the modern style of life in its entirety?}

\section{Synthesized response}

Both groups were divided in their opinions. The old generation agreed that the old traditions and customs be revived and reformed while modern youths are interested in modern lifestyles, however, not including criminality and other social vices. This report is in tandem with the Kwame and lyang studies (as cited in Edih et al., 2022) study which hold that globalization or modernity has caused Africans to appreciate new lifestyles, new tastes, new religion and crave for new desires.

\section{What should be done to curb the ills in modern world?}

\section{Synthesized response}

Both groups agreed on good governance, good laws, religious bodies, the media and all good people should enforce moral values by every legitimate method.

\section{Implications of the waning moral values on African- Nigerian society}

The following negative social behaviours have been observed as prevalent in modern society. These aberrations have eaten and broken the communal fabrics that hold the African-Nigerian traditional culture. A people without a known culture, known tradition and known custom is a generation that has no identity and is therefore, a lost people. The ideology of communality as propounded by Nyereyere of Tanzania is no longer holding waters in Africa. Thus, waning morality, modernity and globalization have caused:

1.increase in moral degradation; loss of moral values (Edih et al., 2022).

2. Increase in infidelity, disloyalty and lack of trust in spouses, broken marriages and families
3. Total relegation of the African traditional culture (Herrington, 2013)

4. Disrespect to parents, elders and constituted authorities

5. Breakdown of institutions; government and private institutions

6. Heightened the spate of get-rich-quick-syndrome through legitimate or illegitimate means.

7. Exposure to immorality, amoral affairs, pornography etc

8. Increase in juvenile delinquencies

9. Access to misgovernment or bad government

10. Corruption, embezzlement and corrupt practices

11. Projects lesbians, hydras, gay marriages, contract marriages (Reshma, 2015)

12. Enables prostitution, frolic lifestyles and party freak's

13. Modernizes, pampers abominable acts and taboos like incest, sodomy, kidnapping, killings for rituals, as pardonable acts.

14. Idolizes madness as new world fashion, trend and entertainment (as cited in Edih et al., 2022)

15. Insults human hood via modern comedies as entertainment business for a living

16. Facilitates the breakdown of laws and order incessant protests, riots and violence

17. Classifies government and education as scam and morality as a fag

18. Respects wealth and money while hardworking and merit are disdain

19. Polarizes and disconnects the social and communal networks

20. Misapply knowledge at the detriment of character and reward

21. Even the government does not respect and adhere to the constitution of the country

22. There is total rot in the land (Reshma, 2015; Ogechukwu et al., 2016)

23. Africans and indeed Nigerians have lost their traditions and culture of high moral values, fidelity to the hidden betrayal of modernity, globalization and the new world

24. That was why, Chinua Achebe cried out in 'Things Fall Apart' that "things had fallen apart, the center could no longer hold" and the "whiteman's religion had destroyed Umuofia clan". The hidden ill in modernity and globalization have destroyed the moral fabrics that bind Africans.

\section{The role of the media}

The world is regarded as a global village, global economy because of the availability of Information and Communication Technologies (ICTs). Several measures have been invented to transmit and transfer messages from one particular point or person to another point or person. The internet is filled with diverse kinds of information that may make and mar the behaviours of the 
people especially modern youths. The role of the media in this regard is to harness the positive aspects of the social media which have pervaded and permeated the social strata in order to polish the behaviours and mindsets of these digital youths. The media, being the power house for broadcasting, entertaining, and informing the general public is a veritable instrument to impact the youths positively. It is therefore, a clarion call to all media houses (public or private media stations) to fight against the moral degeneration in the society.

\section{Conclusion and Recommendations}

The study examined the waning morality and fidelity in African-Nigerian society and the hidden betrayal in modernity and globalization: the role of the media. The study was guided by the four introductory questions. Based on responses to the interview questions, review of literature and critical observation of the pervading sociocultural decay in the society that answers were proferred to the four questions by the following points, that;

1. There is constant war between modernity and/or globalization and the traditions and cultures of Africa and it is clear that the new world is gaining greater momentum.

2. Drivers of the new world are ravaging the traditions and customs of Africa. It is therefore, very difficult to sustain the African-Nigerian traditional cultures.

3. Modernity and globalization are global phenomenal beyond the control of any country or continent. Therefore, the perceived excesses of modernity and globalization can only be managed in the present circumstance.

4. Modern generation of Africa-Nigerian descents are in tune with the new world while the old generation is missing their lovely ancestral heritage.

5. It is therefore, inferred in this context that, "modernity" represents the "forbidden fruit" in the "Garden of Eden" that carries untold consequences if eaten by the first man (Adam and Eve) (Bible narration in Genesis). Africans have eaten the forbidden fruit embedded in modernity and globalization and the aftermaths are biting strong.

\section{Recommendations}

On this basis, the following recommendations were made;

1.Governments of African countries, religious bodies, non-governmental agencies, Kings and Chiefs, heads of families and well-meaning individuals should carry out their responsibilities of advocating and inculcating moral values into the youths, children and wards through town hall meetings, churches and mosques, schools and media platforms.

2. Studies on moral values, norms and customs should be taught in all educational institutions and there should be a reward system for persons who maintain good behaviours and hard work.

3. Government should enact and enforce Laws that will sanction perpetrators of immoral and, abominable acts. 4. All hands should be on deck to fight this global menace through rigorous and consistent advocacy in media stations and social media networks.

5. And governments in Africa should ensure an enabling environment for the private sector to thrive and provide job opportunities for the growing unemployed army in Africa and particularly, Nigeria.

\section{Authors contributions}

The study was carried out by three authors. Author Edih, U.O, conceived the research topic, and drafted the introduction and review of literature. Author Umuze, N. Anthonia, and Author University, E.E read the manuscript, summarized the abstract and conclusion. All authors read and approved the final manuscript for publication.

\section{REFERENCES}

Alphonse, k. (2010). Impact of globalization on traditional Africa religion and cultural conflict. Nova South Eastern University, Fort Lauderdale, Florida, 2(1), 309-322

Chinua, A. (1958). Things fall apart (1st ed). Williams Henneman Ltd

Edih, U. (2020). Communal participation and good governance in Nigeria. International Journal of international Relations, Media and Mass Communication Studies, 2020; 6(1), 35-56

Edih, U. O., Igemohia, F. and Fagawhari, N. D. (2022). Globalization and cultural uniformism: a scientific excursion into the AfricanNigerian traditional culture. African Research Review (in press)

Eze, D. (2014). Nigeria and the crisis of cultural identity in the era of globalization. Journal of African Studies and development, 6(8), 140147; Doi:10.58971/JASD 2014.0294.

Fuchs, C. (2010). Critical globalization studies: an empirical and theoretical analysis of the new imperialism. Science and Society, 74 (2), 215, Doi: 10.1521/SISO2010.74.2.215.

Herrington, I. N. (2013). Globalization and religion in historical perspective: a paradoxical relationship. Centre for Global and International Studies, University of Kansas, USA, 4(1), 145-165; https://doi.org/10.3390/RE14010145

Hill, C. W. (2009) International business competing in the global market place. 10th ed. Grand Hill \& Co

Lemke, L. J. (1993). Discourse, dynamics and social change. Sage Journal. https://doi.org/10.1177/092137409300600107

Nicolaides, A. (2012). Globalization and Americanization: the hijacking of indigenous African cultures. Global Advanced Research Journal of History, Political Sci and Int"I Relation, 1(6), 118-131

Obilade, A. O. (2011). The Nigerian legal system (2nd ed.). Spectrum Books Limited, Ibadan, Nigeria, 2011

Ogechukwu, C. U., Benjamin, C., and Ann, O. (2016). The effect of globalization on African culture: The Nigerian perspective. Journal of Business and Management, 16(4), 62-71; Doi: 10.9790/487X16416271

Reshma, E. F. (2015). Effect of of globalization on transgender in India. International Journal of Humanities and Social Science Invention,4(1), 28-39.

Robinson, W. I. (2007). Theories of globalization (chapter six) in social theory of globalization, the rise of a transnational State theory and 
Edih et al. $\quad 15$

society, 30(2); 157-200; Doi : 10.1023/A.1011077330455

Walter, R. (1987). How Europe underdeveloped Africa. London Boyle-

Looverture. 